\title{
Penerapan Model Pembelajaran Kooperatif STAD Untuk Meningkatkan Kemampuan Pemecahan Masalah Siswa Kelas IV SD Negeri Dukuh 1 Sleman
}

\author{
Eko Pranowo \\ Universitas Alma Ata \\ pranowoeko9@gmail.com \\ Martalia Ardiyaningrum \\ Universitas Alma Ata \\ martaliayudhono87@gmail.com
}

\begin{abstract}
Abstrak
Pembelajaran matematika kelas IV di SD N Dukuh 1 Sleman masih menggunakan model pembelajaran yang monoton dan belum memberikan kesempatan kepada siswa untuk mengembangkan kemampuan pemecahan masalah. Selain itu pencapaian kriteria ketuntasan minimum (KKM) pada materi operasi hitung bilangan bulat masih belum optimal. Penelitian ini bertujuan untuk 1) mengetahui penerapan pembelajaran kooperatif STAD pada konsep bilangan bulat; dan 2) mengetahui peningkatan kemampuan memecahkan masalah konsep bilangan bulat siswa kelas IV SD N Dukuh 1 Sleman tahun pembelajaran 2014/2015. Penelitian ini merupakan penelitian tindakan kelas dengan model Kemis dan Mc Taggart. Subjek penelitian adalah siswa kelas IV SD N Dukuh 1 Sleman sebanyak 17 siswa. Hasil penelitian yang diperoleh menunjukkan bahwa pembelajaran Matematika dengan koperatif STAD dapat meningkatkan kemampuan pemecahan masalah siswa kelas IV SD N Dukuh 1 Sleman. Pada siklus I, presentase siswa yang memiliki nilai tes kemampuan pemecahan masalah lebih dari 70 sebesar $6 \%$, sedangkan pada siklus II persentase yang diperoleh sebesar 100\%. Berdasarkan persentase di atas, kemampuan pemecahan masalah kelas IV SD N Dukuh 1 Sleman mengalami peningkatan. Nilai rata- rata tes siklus I adalah 53,24 dan siklus II adalah 87,35. Berdasarkan hasil postest ini dapat dilihat bahwa terjadi peningkatan terhadap kemampuan pemecahan masalah siswa kelas IV SD N Dukuh 1 Sleman.
\end{abstract}

Kata Kunci: model pembelajaran, kooperatif, STAD, kemampuan pemecahan masalah.

\begin{abstract}
Learning mathematics in 4th grade of SD N Dukuh 1 Sleman still uses a coventional learning model and has not provided opportunities for students to develop problem solving skills. In addition, the achievement of minimum criteria in integer number operation is still not optimal. This study aims to 1) describe the application of STAD cooperative learning to integer concepts; and 2) describe the improvement of problem solving skills in 4th grade students of SD N Dukuh 1 Sleman, academic year of 2014/2015. The method used in this study is a classroom action research method by adopting the Kemmis Mc Taggart model. The subjects of this study were 17 students in 4th grade of SD N Dukuh 1 Sleman. The results of the research obtained showed that STAD cooperative learning in mathematics can improve the problem solving skills of 4 th grade students of SD N Dukuh 1 Sleman. In cycle I, the percentage of students who had test scores on problem solving skills was more than 70 at $6 \%$, while in cycle II the percentage obtained was
\end{abstract}


$100 \%$. Based on the percentage above, the problem solving skills of 4th grade students in SD N Dukuh 1 Sleman has increased. The average value test of the cycle I is 53.24 and the cycle II is 87.35. Based on the research results, it can be concluded that STAD cooperative learning can improve the problem solving skills of 4th grade students of SD N Dukuh 1 Sleman.

Keywords: learning model, cooperative, STAD, problem solving skills.

\section{PENDAHULUAN}

Upaya pemerintah dalam memperbaiki paradigma pendidikan dari tahun ke tahun semakin tampak. Hal itu terlihat dari perubahan dan perbaikan kurikulum, pendekatan, dan metode yang digunakan dalam pembelajaran di kelas. Salah satu bukti realisasi upaya pemerintah tersebut adalah Kurikulum Berbasis Kompetensi (KBK) atau Kurikulum 2004, adalah kurikulum yang mulai diterapkan sejak tahun 2004. Secara materi, sebenarnya kurikulum ini tak berbeda dari Kurikulum 1994, perbedaannya hanya pada cara para murid belajar di kelas. ${ }^{1}$ Kurikulum 2004 ini menuntut para murid untuk aktif mengembangkan keterampilan dan menerapkan ilmu pengetahuan dan teknologi (iptek) dengan tetap menjunjung kerjasama dan solidaritas antar siswa. Dalam makna tersebut, guru bertindak sebagai fasilitator yang memberikan kesempatan kepada siswa untuk dapat mengembangkan kemampuan berpikir dan keaktifan.

Sejak tahun ajaran 2006/2007, diberlakukan kurikulum baru yang bernama Kurikulum Tingkat Satuan Pendidikan (KTSP), yang merupakan penyempurnaan Kurikulum 2004. Kurikulum tersebut diharapkan mampu merubah sistem pembelajaran di kelas termasuk pembelajaran matematika. Pendekatan-pendekatan yang digunakan dalam pembelajaran Matematika bergantung pada berbagai sudut pandang, mulai dari sudut pandang tujuan pembelajaran, cara mencapai tujuan pembelajaran, penyusunan bahan pembelajaran, dan cara penyajian bahan

${ }^{1}$ Loeziana Uce. Realitas actual praksis kurikulum: Analisis terhadap KBK, KTSP dan Kurikulum 2013. (Jurnal Ilmiah Didaktika Februari 2016), hlm. 219. pembelajaran. $^{2}$

Guru juga memiliki peran yang sangat penting dalam pendidikan. Baik buruknya suatu pembelajaran di dalam kelas tergantung dari seorang guru dalam mengelola kelas dan mengaplikasikan metode serta strategi pembelajaran. Metode yang monoton menjadikan siswa bosan dan malas untuk mengikuti pembelajaran. Maka guru harus berusaha menggunakan variasi metode supaya siswa lebih bersemangat belajar. Pada kenyataannya guru kelas IV SD N Dukuh 1 Sleman Yogyakarta hanya menggunakan metode yang monoton, hal ini dibuktikan dengan RPP yang digunakan oleh guru merupakan RPP yang disusun oleh pihak lain tanpa merevisi RPP tersebut sesuai dengan kondisi/kemampuan siswa. Hal ini diduga menjadi salah satu penyebab kurang optimalnya hasil belajar siswa kelas IV SD N Dukuh 1 Sleman.

Berdasarkan hasil wawancara peneliti dengan guru kelas dan hasil pengamatan peneliti terhadap pelaksanaan pembelajaran matematika di kelas, diperoleh beberapa informasi bahwa (1) Pembelajaran sifat-sifat opersai hitung bilangan bulat pada matematika masih jarang dilaksanakan, (2) Dalam pembelajaran sifatsifat opersai hitung bilangan bulat, siswa kurang percaya diri terhadap kemampuannya sendiri dan memiliki kesulitan dalam mengungkapkan ide atau gagasan, (3) Rata-rata nilai kemampuan materi opersai hitung bilangan bulat siswa kelas IV SD N Dukuh 1 Sleman menunjukkan bahwa siswa yang tuntas Kriteria Ketuntasan Minimal (KKM) Mata Pelajaran Matematika (dengan kriteria lebih dari 70) pada tahun 2014/2015

\footnotetext{
${ }^{2}$ Tarigan, Henry Guntur. Menulis Sebagai Suatu Keterampilan Berbahasa. (Bandung: Angkasa 1994) hlm. 22
} 
berjumlah 0 orang dan yang belum tuntas berjumlah 17 orang dari 17 siswa pada saat itu. Hasil belajar ini tentu masih memprihatinkan. Prestasi ini tentunya tak lepas dari faktor pembelajaran yang masih cenderung teacher centered learning sehingga siswa menjadi pasif. Model pembelajaran yang demikian diduga berdampak pada rendahnya kreativitas anak dalam pemecahan masalah matematika yang berdampak pada rendahnya prestasi belajar siswa.

Model pembelajaran mempunyai makna yang lebih luas dari pada strategi, metode, atau prosedur. Suatu model pemelajaran mempunyai empat ciri khusus yang tidak dipunyai oleh strategi atau metode tertentu, yaitu rasional teoritik yang logis yang disusun oleh penciptanya, tujuan pembelajaran yang akan dicapai, tingkah laku mengajar yang diperlukan agar model tersebut dapat dilaksanakan, serta lingkungan belajar yang diperlukan agar tujuan pembelajaran dapat tercapai. ${ }^{3}$

Model pembelajaran ditandai dengan adanya struktur tugas, struktur tujuan, dan struktur penghargaan. Menurut Muslimin pembelajaran kooperatif merupakan pendekatan pembelajaran yang mengutamakan adanya kerjasama antar siswa dalam kelompok untuk mencapai tujuan pembelajaran. ${ }^{4}$ Unsur yang terkandung dalam pembelajaran kooperatif dapat dapat dijelaskan sebagai berikut: 1) siswa bertanggung jawab atas segala sesuatu yang dikerjakan dalam kelompok, 2) siswa harus mengetahui bahwa semua anggota kelompok mmpunyai tujan yang sama, 3) siswa) harus membagi tugas dan tangung jawab yang sama diantara anggota kelompoknya; 4) siswa harus mengikuti kegiatan evaluasi, 5) siswa berbagi kepemimpinan dan membutuhkan keterampilan untuk belajar bersama selama proses belajarnya, dan siswa diminta mempertanggungjawabkan secara individual materi yang ditangani dalam kelompok kooperatif. $^{5}$

${ }^{3}$ Isjoni, Pembelajaran kooperatif (yogyakarta: pustaka pelajar, 2009) hlm.76

${ }^{4}$ Ibid., hlm. 84

${ }^{5}$ Ibrahim, dkk. Pembelajaran Kooperatif.( Surabaya :
Salah satu model pembelajaran kooperatif sederhana yang dapat diterapkan di tingkat pembelajaran sekolah dasar adalah kooperatif tipe Student Team Achievement Division (STAD). Langkah-langkah pembelajaran kooperatif STAD adalah 1) guru menyajikan pelajaran atau menyampaikan materi pembelajaran ke siswa secara klasikal, 2) pembentukan kelompok yang anggotanya 4-5 orang secara heterogen (campuran menurut prestasi, jenis kelamin, suku) dll., 3) guru memberi tugas kepada kelompok untuk dikerjakan oleh anggota 2-5 anggota kelompok, anggota kelompok yang tahu menjelaskan pada anggota lainnya sampai semua anggota dalam kelompok itu mengerti, 4) guru memberi tes/kuis/pertanyaan kepada seluruh siswa secara individu, dan pada saat menjawab tes/kuis/pertanyaan tidak boleh saling membantu di antara anggota kelompok, dan 5) guru memberi penghargaan pada kelompok berdasarkan perolehan nilai peningkatan individual dari skor dasar ke skor kuis. ${ }^{6}$ Berdasarkan penjelasan tersebut, model pembelajaran kooperatif STAD memberikan kesempatan kepada siswa untuk dapat mengembangkan kemampuan siswa dalam menjelaskan dan menyelesaikan masalah yang diberikan oleh guru.

Kemampuan pemecahan masalah merupakan kemampuan yang harus dikuasai oleh siswa sesuai dengan kompetensi dasar yang ada pada tingkat sekolah dasar. Belajar memecahkan masalah dapat melalui pengamatan dalam belajar ini orang dihadapkan pada masalah yang harus dipecahkan dengan mengamati baik-baik. Pemecahan masalah adalah bukan hanya tujuan yang harus dicapai tetapi tindakan yang harus diambil supaya masalah dapat terpecahkan, dan tindakan tersebut belumlah diketahui. Tindakan atau perbuatan itu masih harus ditemukan, dengan mengadakan pengamatan yang teliti dan reorganisasi. Melalui perubahan dalam pengamatan, lahirlah suatum pemahaman yang membawa kita kepemecahan masalah, begitu

University Press 2000) hlm. 23.

${ }^{6}$ Ibid. hlm. 36. 
juga dalam pemecahan masalah matematika. ${ }^{7}$ Polya menjelaskan bahwa pemecahan masalah matematika adalah penyelesaian situasi dalam matematika yang dianggap sebagai masalah bagi orang yang menyelesaikan. ${ }^{8}$

Pemecahan masalah yang tepat merupakan kegiatan yang penting dalam matematika sekolah karena tujuan belajar terpenuhi dengan memecahkan masalah. Belajar dalam memecahkan suatu masalah secara umum merupakan prosedur yang signifikan dalam masyarakat. Hal tersebut sesuai dengan tujuan pembelajaran matematika yaitu menciptakan peserta didik yang bisa bermatematika dalam kehidupan sehari-hari. Kemampuan pemecahan masalah juga diartikan sebagai kemampuan yang ditunjukkan siswa dalam menyelesaikan masalah yang tidak rutin dengan menggunakan langkah-langkah penyelesaian untuk mencapai hasil yang diharapkan. ${ }^{9}$

\section{METODE PENELITIAN}

Penelitian ini merupakan penelitian tindakan kelas dengan mengambil model Kemis dan Mc Taggart. ${ }^{10}$ Penelitian ini memiliki indicator keberhasilan yaitu 73\% siswa mampu mencapai KKM dengan nilai 70. Pertimbangan pencapaian $73 \%$ adalah pada observasi awal tidak ada siswa yang memperoleh nilai melampaui KKM yang telah ditetapkan. Penelitian ini dilaksanakan melalui 2 siklus karena pada siklus kedua target telah tercapai. Setiap siklus terdiri dari tahap perencanaan, tindakan, observasi, dan refleksi.

Subjek penelitian adalah siswa kelas IV SD N Dukuh 1 Sleman Daerah Istimewa Yogyakarta (DIY) sebanyak 17 siswa. Teknik pengumpulan data yang digunakan meliputi hlm. 311

${ }^{7}$ Bell, FH Teaching And Learning Mathematics,... hlm. 115 .

${ }^{8}$ Polya G. How To Solve It A New Aspect OF,...

${ }^{9}$ Ardiyaningrum, Upaya peningkatan kemampuan pemecahan masalah matematis siswa kelas VII SMP Muhammadiyah 9 Yogyakarta melalui penerapan pendekatan pembelajaran problem posing, hlm. 63 .

${ }^{10}$ Suyadi, Panduan Penelitian Tindakan Kelas, hlm. 18 . dokumentasi, observasi, dan tes. Dokumentasi dilakukan untuk memperoleh data seperti data sekolah maupun nilai siswa pada pembelajaran sebelum penelitian. Observasi dilaksanakan untuk memperoleh informasi bahwa setiap tahap model pembelajaran kooperatif STAD telah dilaksanakan sesuai dengan rencana pelaksanaan pembelajaran (RPP). Sedangkan tes digunakan untuk memperoleh data kemampuan pemecahan masalah siswa kelas IV SD N 1 Dukuh Sleman. Instrumen pengumpulan data yang digunakan adalah dokumen, lembar observasi, dan lembar tes kemampuan pemecahan masalah.

Sebelum instrumen digunakan untuk mengambil data di lapangan, terlebih dahulu melalui proses validasi. Validasi yang digunakan adalah validitas isi. Validitas ini merupakan validitas yang dilakukan oleh ahli untuk memastikan bahwa instrument yang disusun telah sesuai dengan kisi-kisi yang akan diukur. Ahli yang ditunjuk dalam validitas isi adalah dosen program studi Pendidikan Guru Madrasah Ibtida'iyah Universitas Alma Ata yang memiliki bidang keahlian pendidikan matematika yaitu Martalia Ardiyaningrum, M.Pd. Setelah melalui proses validasi isi, instrumen telah dinyatakan valid. Data yang dihimpun dari pengumpulan data selanjutnya dianalisis secara deskriptif kuantitatif. Data kuantitatif ini merupakan data kemampuan pemecahan masalah siswa kelas IV yang terdiri dari pretest dan posttest.

\section{HASIL DAN PEMBAHASAN}

Penelitian Tindakan Kelas (PTK) ini telah terlaksana melalui dua siklus. Melalui dua siklus ini, indikator keberhasilan yang telah ditetapkan dapat tercapai. Hasil PTK ini dapat dijelaskan sebagai berikut.

\section{Hasil siklus 1}

\section{Perencanaan Siklus 1}

Perencanaan siklus 1 diawali dengan menyusun RPP untuk 4 pertemuan dengan kompetensi dasar terdiri dari mengurutkan bilangan bulat, menjumlahkan bilangan bulat, mengurangkan bilangan bulat, dan melakukan 
operasi hitung campuran. Dalam RPP telah diuraikan langkah pelaksanaan pembelajaran dengan model kooperatif STAD.

\section{Tindakan Siklus 1}

Pelaksanaan siklus 1 diawali dengan pemberian tes awal (pretest) kemampuan pemecahan masalah kepada siswa. Hasil yang diperoleh dari pretest ini dapat dilihat pada table di bawah ini:

Tabel 1.

\begin{tabular}{lcc}
\hline \multicolumn{1}{c}{ Kategori } & $\begin{array}{c}\text { Jumlah } \\
\text { (siswa) }\end{array}$ & $\begin{array}{c}\text { Persentase } \\
(\%)\end{array}$ \\
\hline Tuntas KKM & 0 & 0 \\
TidakTuntas KKM & 17 & 100 \\
\hline Total & 17 & 100 \\
\hline
\end{tabular}

Berdasarkan data di atas tampak bahwa sebelum dilaksanakan pembelajaran matematika materi bilangan bulat, kemampuan pemecahan masalah matematis siswa masih rendah. Hal ini diduga karena siswa memang belum mendapatkan materi tentang bilangan bulat dari luar sekolah.

Setelah siswa diberikan pretest kemampuan pemecahan masalah, langkah selanjutnya adalah pelaksanaan pembelajaran siklus pertama. Siklus pertama ini dilaksanakan dalam empat kali pertemuan. Pembelajaran matematika menggunakan model pembelajaran kooperatif STAD tersebut dilaksanakan sesuai dengan rencana pembelajaran yang telah ditetapkan. Langkah pembelajaran kooperatif STAD yang telah dilaksanakan diuraikan sebagai berikut:

1) peneliti memberikan penjelasan tentang materi yang telah ditetapkan untuk pertemuan tersebut.

2) peneliti membagi siswa ke dalam 4 kelompok, dengan jumlah anggota setiap kelompok antara 4-5.

3) Peneliti memberikan tugas yang tertuang dalam lembar kerja siswa (LKS) 1, selanjutnya LKS 1 tersebut dikerjakan secara berkelompok. Dalam LKS 1, soal yang diberikan kepada siswa, lebih mengarah pada masalah matematika yaitu soal yang tidak rutin dan dikaitkan dengan konteks kehidupan sehari-hari. Setelah itu, siswa menyampaikan hasil diskusi kelompok di depan kelas dan peneliti memberikan penguatan terhadap hasil diskusi kelas.

4) Peneliti memberikan kuis 1 kepada siswa untuk dikerjakan secara mandiri.

5) Guru memberikan penghargaan kepada dua kelompok yang memperoleh nilai tertinggi berupa ucapan selamat dan tepuk tangan. Peneliti juga memberikan penghargaan kepada siswa yang meraih nilai tertinggi.

Setelah proses pembelajaran matematika pada siklus pertama selesai, siswa diberikan posttes kemampuan pemecahan masalah. Data nilai posttest kemampuan pemecahan masalah tersaji pada table di bawah ini:

Tabel 2.

\begin{tabular}{lcc}
\hline Kategori & $\begin{array}{c}\text { Jumlah } \\
\text { (siswa) }\end{array}$ & $\begin{array}{c}\text { Persentase } \\
(\%)\end{array}$ \\
\hline Tuntas KKM & 1 & 6 \\
TidakTuntas KKM & 16 & 94 \\
\hline Total & 17 & 100 \\
\hline
\end{tabular}

Berdasarkan tabel 2 di atas tampak bahwa jumlah siswa dengan nilai di atas KKM hanya satu orang atau setara dengan $6 \%$. Hasil ini menunjukkan bahwa dalam siklus 1 indikator keberhasilan penelitian tindakan kelas ini belum dapat dicapai, yang berarti penelitian harus dilanjutkan pada siklus kedua.

\section{Observasi Siklus 1}

Observasi dilakukan dengan menggunakan pedoman dan lembar observasi yang telah divalidasi. Observasi dilaksanakan untuk mengamati jalannya proses pembelajaran di kelas telah sesuai dengan rencana yang ditetapkan oleh peneliti. Observasi ini dilakukan oleh wali kelas IV SD N Dukuh 1 Sleman. Objek pengamatan meliputi aktifitas peneliti. Hasil observasi terhadap aktifitas peneliti pada 4 kali pertemuan pembelajaran siklus 1 seperti pada tabel 3.

Berdassarkan hasil observasi terhadap aktifitas peneliti diperoleh fakta bahwa persertase aktifitas peneliti masih dalam kategori 
Tabel 3.

\begin{tabular}{cccc}
\hline $\begin{array}{c}\text { Pertemuan } \\
\text { ke- }\end{array}$ & $\begin{array}{c}\text { Jumlah } \\
\text { Skor }\end{array}$ & $\begin{array}{c}\text { Persentase } \\
\text { Aktifitas (PA) }\end{array}$ & Kategori \\
\hline 1 & 31 & $62 \%$ & Kurang \\
2 & 32 & $64 \%$ & Kurang \\
3 & 33 & $66 \%$ & Kurang \\
4 & 34 & $68 \%$ & Kurang \\
\hline
\end{tabular}

Keterangan

$\begin{array}{lll}90 \% & <\mathrm{PA} \leq 100 \% & : \text { sangat baik } \\ 80 \% & <\mathrm{PA} \leq 90 \% & : \text { baik } \\ 70 \% & <\mathrm{PA} \leq 80 \% & : \text { cukup } \\ 60 \% & <\mathrm{PA} \leq 70 \% & : \text { : kurang } \\ 0 \% & \leq \mathrm{PA} \leq 60 \% & \text { : sangat kurang }\end{array}$

kurang yang berarti bahwa peneliti belum melaksanakan pembelajaran matematika dengan model kooperatif STAD belum sepenuhnya mengacu pada RPP yang telah ditetapkan. Hal ini menunjukkan bahwa perlunya perbaikan proses pelaksanaan pembelajaran kooperatif STAD pada siklus selanjutnya. Hasil observasi ini digunakan sebagai dasar dalam tahap selanjutnya yaitu refleksi.

\section{Refleksi}

Pada kegiatan pembelajaran siklus 1 menunjukkan tidak ada permasalahan dalam perumusan rencana pelaksanaan pembelajaran (RPP). Jadwal jam pembelajaran pertemuan telah sesuai dengan kebutuhan pelaksanaan pembelajaran. Sedangkan pada tahap pelaksanaan pembelajaran matematika menggunakan model kooperatif STAD ditemukan beberapa kendala yang dapat diuraikan berikut ini. Pertama, kondisi kelas belum terkendali saat peneliti menjelaskan materi pelajaran kepada siswa dan kelas menjadi ramai. Kedua, hanya beberapa siswa yang berani bertanya kepada guru. Ketiga, seluruh siswa belum memiliki keberanian untuk memberikan pendapat atas hasil kerja temannya. Keempat, kurangnya manajemen waktu dari peneliti dalam melaksanakan pembelajaran matematika.

Berdasarkan kendala yang ditemukan dalam siklus pertama, perlu dilakukan perbaikan terhadap kendala tersebut dengan tujuan pada pelaksanaan pembelajaran siklus kedua kendala tersebut dapat teratasi. Adapun rencana perbaikan siklus kedua dapat dijelaskan berikut ini. Pertama, peneliti lebih tegas dalam menjelaskan setiap langkah pembelajaran dengan tetap berfokus kepada siswa. Kedua, peneliti memberikan motivasi kepada siswa untuk berani bertanya dalam hal apapun terutama dalam pembelajaran yang belum mereka pahami termasuk matematika. Ketiga, bersama siswa, peneliti membahas pekerjaan siswa lainnya dan meminta siswa untuk maju ke depan jika merasa ada yang salah dari jawaban siswa lainnya. Keempat, memperbaiki manajemen waktu dan manajemen pengelolaan kelas dengan waktu yang tersedia.

\section{Hasil Siklus II \\ Perencanaan SIklus II}

Pada tahap ini, peneliti menyusun perencanaan berdasarkan hasil refleksi dari siklus pertama. Siklus kedua dilaksanakan melalui empat kali pertemuan. Kegitan yang dilakukan peneliti adalah mempersiapkan RPP dengan menyesuaikan hasil refleksi siklus I, mempersiapkan lembar observasi, dan mempersiapkan alat peraga berupa garis bilangan.

\section{Tindakan Siklus II}

Tindakan pada siklus kedua ini dilakukan melalui empat kali pertemuan. dan setiap pertemuan menggunakan langkah-langkah pembelajaran kooperatif tipe STAD yang telah ditetapkan. Setelah pembelajaran siklus kedua dilaksanakan, setiap siswa diberikan posttest kemampuan pemecahan masalah. Adapun hasil tes kemampuan pemecahan masalah dapat dilihat dari table di bawah ini:

Tabel 4.

\begin{tabular}{lcc}
\hline \multicolumn{1}{c}{ Kategori } & $\begin{array}{c}\text { Jumlah } \\
\text { (siswa) }\end{array}$ & $\begin{array}{c}\text { Persentase } \\
(\mathbf{\% )})\end{array}$ \\
\hline Tuntas KKM & 17 & 100 \\
TidakTuntas KKM & 0 & 0 \\
\hline Total & 17 & 100 \\
\hline
\end{tabular}

Berdasarkan tabel di atas tampak bahwa jumlah siswa dengan nilai di atas KKM 
sebanyak 17 siswa atau setara dengan $100 \%$. Hasil ini menunjukkan bahwa setelah siklus II dilaksanakan, indikator keberhasilan penelitian tindakan kelas ini telah tercapai, yang berarti penelitian dapat dihentikan.

\section{Observasi Siklus II}

Observasi siklus II dilakukan untuk mengamati aktifitas guru dalam melaksanakan pembelajaran kooperatif tipe STAD. Hasil observasi terhadap aktifitas guru pada 4 kali pertemuan pembelajaran siklus 2 adalah sebagai berikut:

Tabel 5.

\begin{tabular}{cccc}
\hline $\begin{array}{c}\text { Pertemuan } \\
\text { ke- }\end{array}$ & $\begin{array}{c}\text { Jumlah } \\
\text { Skor }\end{array}$ & $\begin{array}{c}\text { Persentase } \\
\text { Aktifitas (PA) }\end{array}$ & Kategori \\
\hline 1 & 40 & $80 \%$ & Cukup \\
2 & 41 & $82 \%$ & Baik \\
3 & 42 & $84 \%$ & Baik \\
4 & 44 & $88 \%$ & Baik \\
\hline
\end{tabular}

Keterangan

$$
\begin{array}{lll}
90 \% & <\mathrm{PA} \leq 100 \% & : \text { sangat baik } \\
80 \% & <\mathrm{PA} \leq 90 \% & : \text { baik } \\
70 \% & <\mathrm{PA} \leq 80 \% & : \text { cukup } \\
60 \% & <\mathrm{PA} \leq 70 \% & : \text { kurang } \\
0 \% & \leq \mathrm{PA} \leq 60 \% & : \text { sangat kurang }
\end{array}
$$

Berdassarkan hasil observasi terhadap aktifitas peneliti diperoleh fakta bahwa secara keseluruhan persertase aktifitas peneliti pada siklus II telah masuk dalam kategori baik yang berarti bahwa peneliti telah melaksanakan pembelajaran matematika dengan model kooperatif STAD dengan mengacu pada RPP yang telah ditetapkan.

\section{Refleksi Siklus II}

Berdasarkan nilai akhir siklus II dan hasil observasi, maka dapat diperoleh hasil refleksi sebagai berikut:

1) Hasil tes kemampuan masalah siswa pada siklus II menunjukkan peningkatan yang signifikan, karena lebih dari $73 \%$ siswa telah mencapai KKM. Berdasarkan hasil tersebut, tidak perlu diadakan pengulangan siklus.

2) Hasil observasi pelaksanaan pembelajaran kooperatif tipe STAD telah menunjukkan kriteria baik. Hal ini berarti bahwa pelaksanaan pembelajaran kooperatif tipe STAD telah dilaksanakan dengan baik.

Hasil penelitian tindakan kelas yang telah dilaksanakan melalui 2 siklus terhadap peningkatan kemampuan pemecahan masalah dapat digambarkan melalui diagram batang di bawah ini.

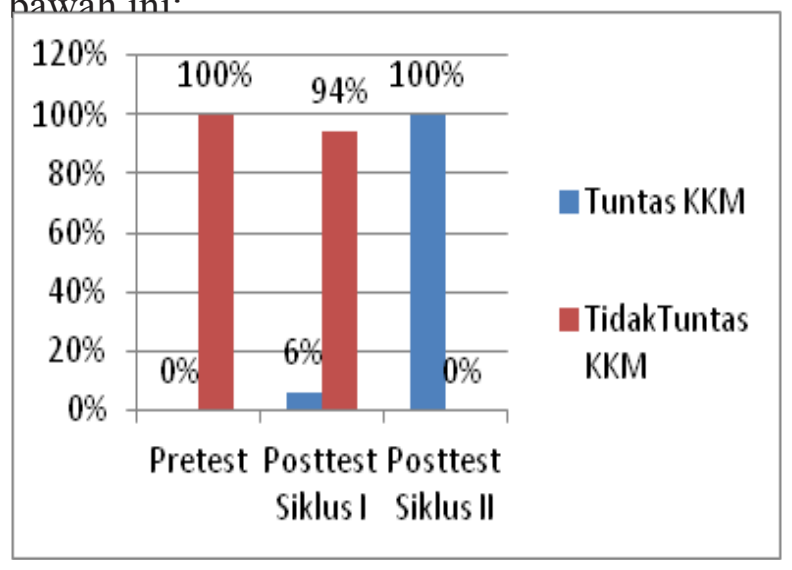

Gambar 1. Peningkatan Nilai Tes Kemampuan Pemecahan Masalah Siswa Kelas IV SD N Dukuh 1 Sleman

Data di atas menunjukkan bahwa terdapat peningkatan penguasaan kemampuan pemecahan masalah siswa kelas IV SD N Dukuh 1 Sleman setelah mengikuti pembelajaran kooperatif tipe STAD melalui dua siklus penelitian tindakan kelas. Sebelum dilaksanakan pembelajaran kooperatif tipe STAD siswa yang memperoleh nilai tes kemampuan pemecahan masalah di atas KKM hanya 0\% dan setelah dilaksanakan pembelajaran kooperatif tipe STAD pada siklus kedua, nilai tes kemampuan pemecahan masalah yang berada di atas KKM terdapat $6 \%$. Hasil ini belum dapat memenuhi kriteria indicator keberhasilan penelitian. Oleh karena itu penelitian ini dilanjutkan pada siklus kedua. Hasil tes kemampuan pemecahan masalah yang diperoleh setelah siklus kedua menunjukkan peningkatan yang signifikan yaitu sebesar 94\%. Hal ini berarti indicator keberhasilan penelitian telah tercapai.

Pelaksanaan pembelajaran kooperatif tipe STAD memberikan kesempatan kepada siswa 
untuk menyelesaikan tugas secara kelompok dan individu. ${ }^{11}$ Pada langkah tersebut merupakan bagian terpenting dalam menanamkan kemampuan pemecahan masalah kepada siswa yaitu dengan memberikan berbagai soal yang melatih penguatan kemampuan pemecahan masalah. Dengan demikian, siswa dapat terbiasa menghadapi soal-soal yang bersifat pemecahan masalah.

Pelaksanaan kegiatan diskusi oleh setiap kelompok, perlu pendampingan dan pengarahan oleh guru. Hal ini memiliki tujuan agar tercipta kerja kelompok yang efektif dan efisien, sehingga tujuan pembelajaran dapat tercapai. Langkah pembelajaran kooperatif yang perlu perhatian adalah presentasi materi pelajaran. Pada langkah ini, membutuhkan motivasi dari guru agar setiap siswa dalam kelompok bersedia menyampaikan hasil kerja kelompoknya di depan kelas. Siswa akan belajar mengungkapkan pendapatnya dengan bahasa yang mereka pahami. Hal tersebut sesuai dengan yang diungkapkan polya: "Pembelajaran kooperatif meiliki keunggulan yaitu dapat mengembangkan kemampuan dan mengungkapkan ide atau gagasan dengan katakata secara verbal dan membandingkannya dengan ide - ide orang lain. ${ }^{12}$

\section{KESIMPULAN}

Berdasarkan hasil dan pembahasan di atas, kesimpulan terhadap hasil tersebut dapat dijelaskan berikut ini. Pertama, penetrapan model pembelajaran kooperatif tipe STAD dilakukan melalui langkah-langkah berikut, 1) pemberian motivasi, 2) pembetukan kelompok, 3) presentasi materi pelajaran, 4) pelaksanaan kerja kelompok, 5) pelaksanaan kuis, 6) pemberian hadiah kepada kelompok pemenang. Kedua, model pembelajaran kooperatif tipe STAD dapat meningkatkan kemampuan pemecahan masalah konsep bilangan bulat yaitu konsep pengukuran bilangan bulat pada siswa kelas IV SD N Dukuh 1 Sleman. Setelah melalui 2 siklus penelitian tindakan kelas, persentase nilai kemampuan pemecahan masalah siswa yang lebih dari KKM meningkat dari $0 \%$ menjadi $100 \%$. Hal ini menunjukkan, bahwa pembiasaan siswa dalam menyelesaikan soal-soal bersifat pemecahan masalah matematika akan dapat meningkatkan kemampuan pemecahan masalah siswa pula.

\section{DAFTAR PUSTAKA}

Ardiyaningrum, M., Upaya Peningkatan Kemampuan Pemecahan Masalah Matematis Siswa Kelas VII SMP Muhammadiyah 9 Yogyakarta melalui Penerapan Pendekatan Pembelajaran Problem Posing, (Literasi Jurnal Ilmu Pendidikan, No. 1, Vol. 4, 2013)

Bell, F.H., Teaching and Learning Mathematics (In Secondary Schools), (Lowa: Dubuque, 1978).

Ibrahim, dkk, Pembelajaran Kooperatif, (Surabaya: University Press, 2000).

Isjoni, Pembelajaran Kooperatif, (Yogyakarta: Pustaka Pelajar, 2009).

Loeziana Uce. Realitas actual praksis kurikulum: Analisis terhadap KBK, KTSP dan Kurikulum 2013. (Jurnal Ilmiah Didaktika No. 2, Vol. 16, Februari 2016). Polya, G., How to Solve It (A New Aspect of Mathematical Method) second Edition, (Garden City: Doubleday \& Company Inc, 1957).

Tarigan, H.G., Menulis Sebagai Suatu Keterampilan Bahasa, (Bandung: Angkasa, 1994).

Suyadi, Panduan Penelitian Tindakan Kelas, (Yogyakarta: Diva Press, 2012).

\footnotetext{
${ }^{11}$ Ibrahim, dkk. Pembelajaran Kooperatif. (Surabaya: University Press 2000), hlm 23.

${ }^{12} \mathrm{Ibid}, \mathrm{hlm} 50$.
} 